
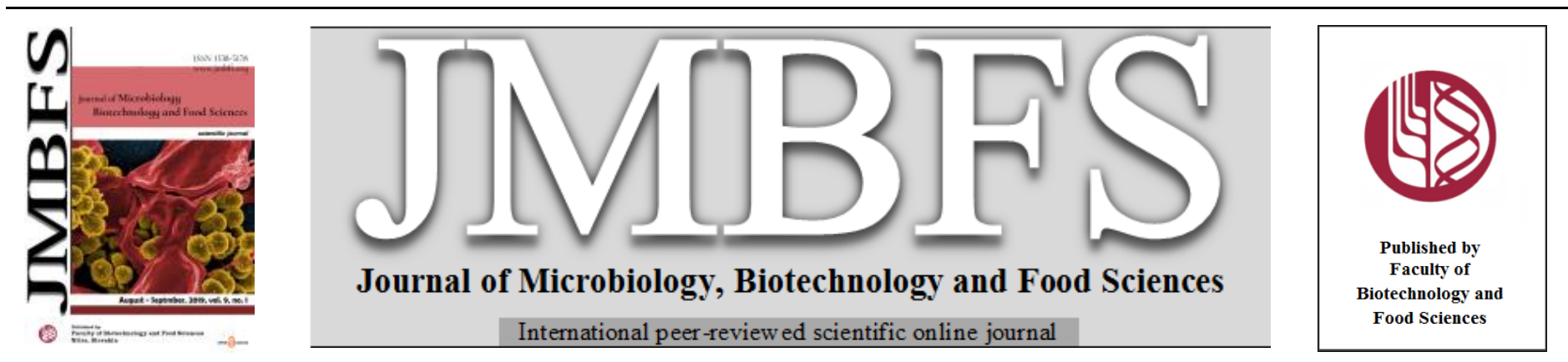

\title{
MODELING AND OPTIMIZATION OF MASHING PROCESS IN BEER PRODUCTION WITH RICE ADJUNCT
}

\author{
Samavath Mallawarachchi, Sanja Gunawardena*
}

Address(es):

Department of Chemical and Process Engineering, University of Moratuwa, Moratuwa 10400, Sri Lanka.

*Corresponding author: $\underline{\text { sanjag@uom.lk }}$

doi: 10.15414/jmbfs.2019.9.1.104-110

ARTICLE INFO

Received 16.3. 2018

Revised 17.3. 2019

Accepted 21. 3. 2019

Published 1. 8. 2019

Regular article

open ${ }_{\text {Access }}$

\begin{abstract}
Adjuncts like rice, wheat and sorghum are used by beer manufacturers worldwide to reduce the cost of production by replacing malt as a starch source. Rice is the most widely used adjunct in Asian countries. Understanding the enzyme kinetics in mashing process is vitally important to maximize sugar yield at a minimum cost. In this research, a semi-empirical model was developed for the mashing process, based on enzyme kinetic equations and experimental results; and this model was used to optimize the operating conditions when enzymes are not added externally. As predicted by the model, when $30 \%(w / w)$ of rice was used as an adjunct the maximum sugar yield can be obtained at $56^{\circ} \mathrm{C}$ and $6.5 \mathrm{pH}$, and the optimum temperature for mashing process increases with acidity. Since the acidity of solution increases during the mashing process due to the formation of organic acids, use of an increasing temperature profile is recommended to get the maximum output from the mashing process.
\end{abstract}

Keywords: mashing, wort, rice adjunct, enzyme kinetics, model, optimization

\section{INTRODUCTION}

Beer is one of the most consumed beverages in the global market, with a global production of 1.93 billion hectoliters in 2015 ("Beer production worldwide from 2008 to 2015, by region "). Two main stages in beer production are mashing and fermentation. Mashing is the conversion of starch from malt or other cereals into simple fermentable sugars via enzymatic reactions (Szwed Lukasz, Tomaszewska-Ciosk, \& Blażewicz, 2014). The product from the mashing process is a solution with high sugar content called wort. During fermentation, the fermentable sugars in wort are converted to ethanol.

Maximizing the conversion of starch to fermentable sugars is essential to maximize the efficiency of beer production, making mashing is a process of crucial importance. While amylase is the main enzyme required for the mashing process, other enzymes like proteases and peptidases are also involved in mashing (Owuama, 1997). Activity of amylase enzyme depends on a number of factors including temperature, $\mathrm{pH}$ and composition of solution, and a maximum starch conversion can be obtained through optimization of these parameters. Two types of amylase are involved in the mashing process; $\propto$-amylase, which hydrolyses long chain starch molecules into shorter chains, and $\beta$-amylase, which further hydrolyses those short chains into simple sugars. $\propto$-amylase is reported to perform optimally around $6.5-7.0 \mathrm{pH}$ and $55^{\circ} \mathrm{C}$ while $\beta$-amylase shows highest activity around 4.0-5.5 $\mathrm{pH}$ and $65^{\circ} \mathrm{C}$ temperature (Biazus et al., 2009; Sundarram \& Murthy, 2014).

Barley malt is the main raw material used in beer production, as it contains both starch and the amylase enzyme required for starch hydrolysis. Amylase is contained in the embryo, endosperm and the aleurone layer of the malt grain (Briggs, 1964). In countries where barley is not grown as an agricultural crop, brewing beer with $100 \%$ malt is not economically feasible. Therefore, other less expensive grains like rice, wheat and sorghum are added as adjuncts during beer production in commercial breweries, thus reducing the production expenses. (Lloyd, 1986).

The percentage of adjuncts used in industrial breweries ranges from 10 to $25 \%$ in Europe and 35 to $45 \%$ in USA, while in some African countries it is as high as $50-70 \%$ (Ogbeide, 2011). When deciding the amount of adjuncts to be used for brewing, several factors have to be considered including required beer quality, cost of adjunct, starch content in adjunct, available mashing technology, fermentation time and whether enzymes are added externally. An added advantage of some adjuncts is the improvement and stabilization of the flavour of beer. One of the main limitations in adjuncts is the low nitrogen content. As most types of adjuncts has a lower nitrogen content than malt, use of too much adjuncts can lead to a reduced Free Amino Nitrogen (FAN) content in wort.
(Bajomo \& Young, 1992; Pliansrithong, Usansa, \& Wanapu, 2013) Since FAN is an essential component for the growth of yeast cells, low levels of FAN can lead to longer fermentation time (Lekkas, Stewart, Hill, Taidi, \& Hodgson, 2005). Therefore, maintaning moisture, total nitrogen and FAN content within the desirable range is essential when adjuncts are used in brewing. Requirement of gelatinization is another disadvantage in using adjuncts, as it can lead to longer operating time and higher capital investment (Poreda, Czarnik, Zdaniewicz, Jakubowski, \& Antkiewicz, 2014).

In Asian countries rice is used as an adjunct in brewing. Rice is an excellent source of carbohydrates, containing $70-74 \%$ (w/w) of starch compared to the 58$64 \%$ (w/w) of starch in malt (Greenwood \& Thomson, 1959; Kongkaew, Usansa, \& Wanapu, 2012; Williams, Wu, Tsai, \& Bates, 1958). Added advantages due to the use of rice as an adjunct include increase of the colloidal stability, and reduction of haze protein content, which will improve the clarity of beer (Asante, 2008; Kongkaew et al., 2012). The main limitation in using rice is that, unlike malt, rice does not contain the amylase enzyme required to break down starch into fermentable sugars. Therefore, in most commercial breweries amylase is added externally to facilitate starch conversion (Poreda et al., 2014). However, use of enzymes also can cause several problems including high cost incurred in procuring the enzymes and reduction in foam potential in beer. In addition, negative customer impression about genetically modified enzymes can lead to marketing difficulties.

Most of the previous studies on mashing process have focused on developing empirical mashing curves and analyzing the reaction kinetics of commercial enzymes used in mashing. However, the possibility of utilizing amylase naturally present in malt is an area which is not investigated in depth. Understanding the enzyme kinetics during the mashing process is essential to obtain a high sugar yield at a minimum cost, and a semi-empirical model based on well established theories is more robust to operating conditions than a fully empirical model. The focus of this study is to optimize the operating conditions of the mashing process using enzymes naturally present in malt, without external enzyme addition. This is achieved by developing a semi-empirical model based on Michaelis-Menten enzyme kinetic equations and experimental results to explain the effect of temperature and $\mathrm{pH}$ on enzymatic activity during mashing.

\section{MATERIALS AND METHODS}

\section{Materials}

Malt used in all these experiments were provided free of charge by the AsiaPacific Brewery, Sri Lanka, and Sri Lankan white rice (oryza sativa) was 
purchased from the local market. White rice was specifically selected due to high starch content, market availability and low price (Williams et al., 1958). All experiments were conducted using same rice and malt stocks.

\section{Determination of starch content}

The starch content in malt and rice was determined using Fehling's method. The starch sample was digested with $20 \mathrm{ml}$ of concentrated $\mathrm{H}_{2} \mathrm{SO}_{4}$ and neutralized with $0.1 \mathrm{~N} \mathrm{NaOH}$. This solution was volumed up to $250 \mathrm{ml}$ and titrated with Fehling's A and B solutions to determine the sugar content. The starch concentration in the sample was calculated based on the sugar content.

\section{Mashing process}

The mashing process was based on previous research (Mallawarachchi, Bandara, Dilshan, Gunawardena, \& Ariyadasa, 2016). Mass percentages of malt and rice were varies while keeping the total weight of malt and rice constant at $20 \mathrm{~g}$. Initially malt and rice were ground separately for $5 \mathrm{~s}$ at $14000 \mathrm{rpm}$ using Jaipan IS-4250 grinder. Malt was ground without removing the husk while the husk of rice had been removed beforehand.

The rice was gelatinized by cooking for 10 minutes at $100^{\circ} \mathrm{C}$. Gelatinized rice was mixed with malt and $100 \mathrm{ml}$ of water in conical flasks by thorough shaking. $\mathrm{pH}$ of the solution was adjusted by adding $0.5 \mathrm{M} \mathrm{HCl}$ or $0.5 \mathrm{M} \mathrm{NaOH}$. The solutions were incubated in a water bath at selected temperature for 2 hours for the reactions to take place while stirring the solutions continuously. $1 \mathrm{ml}$ of each sample was extracted at predetermined time intervals, and total fermentable sugar content was determined.

\section{Determination of fermentable sugars}

The fermentable sugars were determined using Phenol-sulphuric acid method, a colorimetric method based on the reaction of sugars with phenol and sulphuric acid producing colored derivatives (Albalasmeh, Berhe, \& Ghezzehei, 2013; Buckee \& Hargitt, 1978). $1 \mathrm{ml}$ of each sample was extracted using a pipette and diluted 500 fold using serial dilution method. $1 \mathrm{ml}$ of $5 \%(\mathrm{w} / \mathrm{w})$ phenol solution and $5 \mathrm{ml}$ of concentrated $\mathrm{H}_{2} \mathrm{SO}_{4}$ was added to $1 \mathrm{ml}$ of the diluted solution. The samples were thoroughly mixed by vortexing for 1 minute, incubated for 10 minutes at room temperature for colour development and cooled for 5 minutes in an ice bath. Their absorbance was measured using spectrophotometer (SHIMADZU UV-1800 Model) at $489 \mathrm{~nm}$, the wavelength which gives highest absorbance for the phenol-sulphuric acid methid (Mallawarachchi et al., 2016) Absorbance readings were converted to concentration using a calibration curve prepared using standard sugar samples.

\section{Analysis of results}

Initially a statistical model was developed based on experimental results to select the optimum temperature and composition ranges. The data from these experiments were analyzed using the Surface Fitting Toolbox in Matlab ${ }^{\circledR}$ by Mathworks.

The effect of temperature and $\mathrm{pH}$ were further analyzed using the semi-empirical model based on Michaelis-Menten kinetics. The rice: malt ratio was kept constant at $30: 70$ as it gave the highest sugar yield, and the mashing curves were obtained at temperatures of $60^{\circ} \mathrm{C}, 65^{\circ} \mathrm{C}$ and $70^{\circ} \mathrm{C}$ and the $\mathrm{pH}$ values of 4.0 and 5.5 . These temperature and $\mathrm{pH}$ ranges were selected to enclose the optimum conditions for both $\alpha$ and $\beta$ amylase.

Matlab ${ }^{\circledR}$ software was used to numerically determine the coefficients of the model. The model based on Michaelis-Menten kinetics was simulated using Simulink tool in Matlab ${ }^{\circledR}$. The coefficients of the model were determined by substituting a range of values for each coefficient, calculating the Sum of Squared Errors (SSE) and selecting the combination which minimized the SSE. Calculation of SSE was done using Microsoft Excel.

\section{RESULTS AND DISCUSSION}

\section{Kinetic Model}

According to Michaelis-Menten enzyme kinetics, an enzymatic reaction occurs in two steps: the reversible bonding of enzyme to the substrate forming enzymesubstrate intermediate, and conversion of enzyme-substrate intermediate into products. The second step is considered as the rate limiting step.

$\mathrm{E}+\mathrm{S} \underset{\mathrm{k}_{2}}{\stackrel{\mathrm{k}_{1}}{\rightleftarrows}} \mathrm{ES} \stackrel{\mathrm{k}_{3}}{\longrightarrow} \mathrm{E}+\mathrm{P}$

The rate of an enzymatic reaction is expressed by Michaelis-Menten equation.
$\mathrm{r}=\frac{\mathrm{d}(\mathrm{P})}{\mathrm{dt}}=\frac{\mathrm{r}_{\max }(\mathrm{S})}{\mathrm{K}_{\mathrm{m}}+(\mathrm{S})}$ where

$\mathrm{r}_{\max }=\mathrm{k}_{3}[\mathrm{E}]_{0}$ and $\mathrm{K}_{\mathrm{m}}=\mathrm{k}_{2} / \mathrm{k}_{1} \quad$ (Schuler \& Kargi, 2002)

However, the values of $r_{\max }$ and $\mathrm{K}_{\mathrm{m}}$ are dependent on temperature and $\mathrm{pH}$. $\alpha$ amylase contains two acidic groups, Asp231 and Glu261 which contributed to catalytic activity. Glu261 acts as a proton donor and protonates the glycosidic oxygen in starch molecules, while Asp231 acts as a nucleophile and attacks the terminal carbon atom. According to literature, at low $\mathrm{pH}$ values the nucleophilic group is protonated, thus preventing its catalytic activity, and at high $\mathrm{pH}$ values, the proton donor (Glu261) is deprotonated, making it impossible to initiate the hydrolysis of starch (Nielsen, Borchert, \& Vriend, 2001). While other amylases such as $\beta$-amylase and glucoamylase also can contribute to starch hydrolysis, $\alpha-$ amylase is usually a dominant enzyme present in barley malt. The deprotonation of proton donor and the protonation of nucleophilic group can be expressed by the following equations.



$\mathrm{EH}+\mathrm{H}^{+} \stackrel{\mathrm{k}_{5}}{\longrightarrow} \mathrm{EH}_{2}^{+}$

The effect of these two reactions on the reaction rate can be expressed by $\mathrm{K}_{\mathrm{m}}=\mathrm{K}_{\mathrm{m}}^{\prime}\left(1+\frac{\mathrm{K}_{4}}{\left[\mathrm{H}^{+}\right]}+\frac{\left[\mathrm{H}^{+}\right]}{\mathrm{K}_{5}}\right) \quad$ (Schuler \& Kargi, 2002)

The effect of temperature on enzymatic performance is twofold. As the temperature increases, the kinetic energy of molecules will increase, thus increasing reaction rate. This is expressed by Arrhenius equation

$\mathrm{K}=A \mathrm{e}^{-\frac{\mathrm{E}}{\mathrm{RT}}}$

On the other hand, high temperatures will lead to denaturation of enzymes, thus lowering the reaction rate. Kinetics for the thermal denaturation of enzymes are given by

$\frac{\mathrm{d}[\mathrm{E}]}{\mathrm{dt}}=-\mathrm{k}_{\mathrm{d}}[\mathrm{E}]$

Where $\mathrm{k}_{\mathrm{d}}$ also varies with temperature according to Arrhenius equation (Schuler \& Kargi, 2002)

Since the same malt stocks are used for all experiments, the initial Amylase concentration is taken as proportional to the mass of malt.

$\mathrm{E}_{0} \propto \mathrm{m}_{\mathrm{m}}$

As the solution is stirred continuously during the mashing process, it is considered that all the starch is present either in dissolved form or in suspension, without precipitating. Thus, all starch molecules in the solution are free to react with the enzyme. The substrate concentration remaining after a certain time can be written as a function of initial mass of rice, starch fraction by weight in rice, initial mass of malt, starch fraction by weight in malt, volume of sample and product concentration. Since the mashing process spans over a considerable period of time, the diffusion of substrate molecules is not considered as a rate limiting factor. Therefore, the substrate concentration can be expressed as

$[S]=\frac{m_{r} x_{r}+m_{m} x_{m}}{V}-[P]$

This model was simulated using the Simulink tool in Matlab ${ }^{\circledR}$. The Simulink representation of the model is shown in Figure 1. 


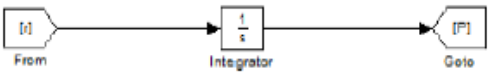

b)

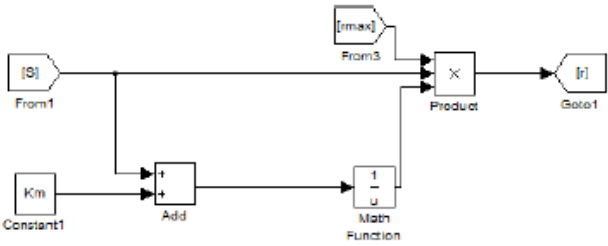

c)

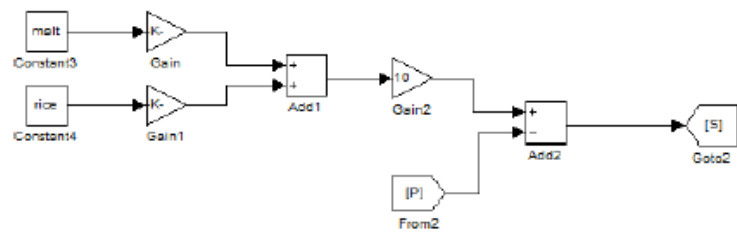

d)

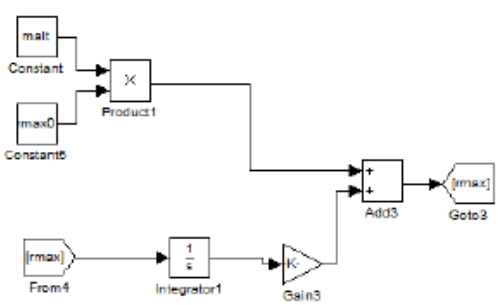

Figure 1 Simulink representation of the mathematical model for the mashing process consisting of a) expression of product concentration as a function of reaction rate b) expression of reaction rate as a function of substrate concentration, c) expression of substrate concentration as a function of initia mass of rice, starch fraction by weight in rice, initial mass of malt, starch fraction by weight in malt, volume of sample and product concentration, and d) expression of the effect of thermal denaturation of enzymes.

\section{Determination of starch content}

Determination of starch contents in malt and rice was required to solve the mathematical model. According to the experimental results starch content of malt and rice were $63 \%(\mathrm{w} / \mathrm{w})$ and $73 \%(\mathrm{w} / \mathrm{w})$ respectively. These results agreed with the literature values of 58-64\% starch for malt and 70-74\% for rice (Greenwood \& Thomson, 1959; Kongkaew et al., 2012; Williams et al., 1958), which meant that rice and malt used for this experiment could be taken as representative of all rice and malt types used in commercial breweries.

\section{Development of semi-empirical model}

The objective of the experiment was to identify the optimum conditions for the mashing process. Initially, in order to estimate the optimum composition and temperature ranges, reaction time was kept constant at 2 hours and final sugar concentration was determined for different compositions and operating temperatures. Impact of temperature and rice content on sugar yield was analyzed using the surface fitting tool in Matlab ${ }^{\circledR}$ as shown in Figure 2.

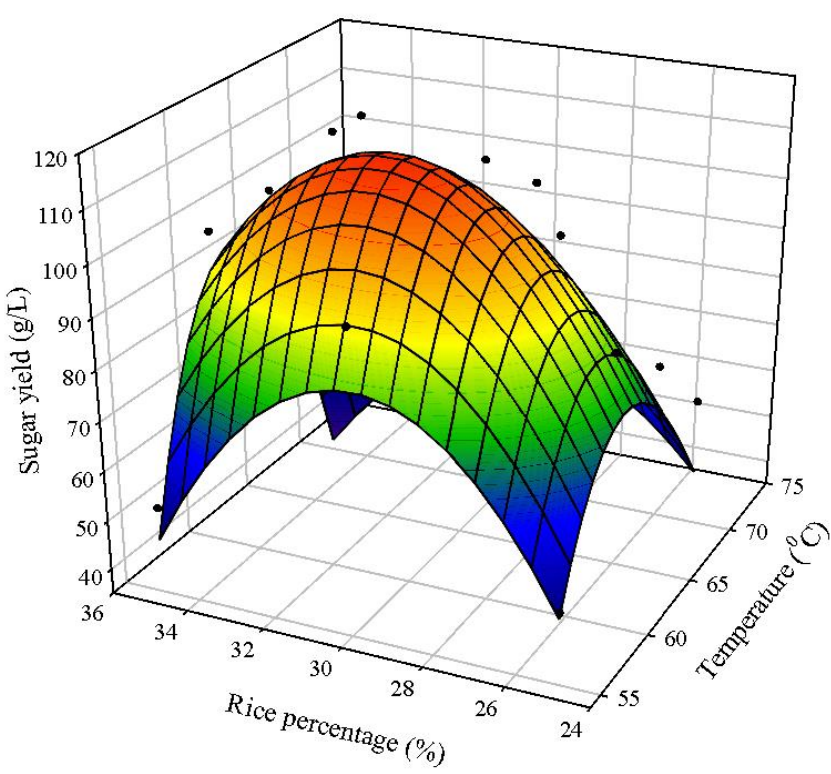

Figure 2 Surface fit for variation of sugar yield with Temperature and rice percentage created using Matlab ${ }^{\circledR}$ based on experimental results

According to the surface obtained, the optimum temperature for the mashing process was $62^{\circ} \mathrm{C}$ and the optimum rice percentage was $30 \%(\mathrm{w} / \mathrm{w})$. However, the sum of squared errors (SSE) for this model was 1183 and the co-efficient of determination $\left(\mathrm{R}^{2}\right)$ was 0.8984 . The high $\mathrm{SSE}$ value and the considerable deviation of $\mathrm{R}^{2}$ value from 1 implied that this statistical model was not highly accurate in predicting mashing behavior. Comparing the fitted curve with actual readings, it could be seen that although the model was accurate when the rice percentage was close to $35 \%$, the curve was considerably deviated from experimental values in the temperature range of $60-65^{\circ} \mathrm{C}$ and the rice composition range of $28-32 \%$. Therefore, a better model based on MichaelisMenten kinetics was required to predict the optimum conditions.

Coefficients of the semi-empirical model were determined by substituting a range of values for each coefficient, calculating the SSE for each combination and selecting the combination which gave the minimum SSE. The temperature range for the experiments was selected as $50-70{ }^{\circ} \mathrm{C}$ and $\mathrm{pH}$ range was selected as 4-7 so as to enclose the optimum temperature and $\mathrm{pH}$ ranges given in literature. $95.3 \%$ confidence intervals were constructed for each parameter based on the standard deviations in experimental results. Experimentally determined model coefficients at selected temperature and $\mathrm{pH}$ values are given in Table 1.

Table 1 Experimentally determined model coefficients with $95.3 \%$ confidence intervals

\begin{tabular}{lllll}
\hline Temp & $\mathbf{p H}$ & $\mathbf{r}_{\mathbf{m a x}}$ & $\mathbf{K}_{\mathbf{d}}$ & $\mathbf{K}_{\mathbf{m}}$ \\
\hline 50 & 4 & $0.1 \pm 0.002$ & $0.003 \pm 0.0005$ & $60.5 \pm 1.5$ \\
\hline 50 & 5.5 & $0.1 \pm 0.002$ & $0.003 \pm 0.0005$ & $16.5 \pm 2$ \\
\hline 50 & 7 & $0.1 \pm 0.002$ & $0.003 \pm 0.0005$ & $7 \pm 1$ \\
\hline 60 & 4 & $0.125 \pm 0.004$ & $0.004 \pm 0.001$ & $42.5 \pm 2$ \\
\hline 60 & 5.5 & $0.125 \pm 0.004$ & $0.004 \pm 0.001$ & $9 \pm 2$ \\
\hline 60 & 7 & $0.125 \pm 0.004$ & $0.004 \pm 0.001$ & $4 \pm 2$ \\
\hline 65 & 4 & $0.14 \pm 0.002$ & $0.006 \pm 0.0005$ & $46 \pm 1.5$ \\
\hline 65 & 5.5 & $0.14 \pm 0.002$ & $0.006 \pm 0.0005$ & $13 \pm 0.5$ \\
\hline 65 & 7 & $0.14 \pm 0.002$ & $0.006 \pm 0.0005$ & $10 \pm 1$ \\
\hline 70 & 4 & $0.145 \pm 0.006$ & $0.013 \pm 0.001$ & $35 \pm 5$ \\
\hline 70 & 5.5 & $0.145 \pm 0.006$ & $0.013 \pm 0.001$ & $13 \pm 1.5$ \\
\hline 70 & 7 & $0.145 \pm 0.006$ & $0.013 \pm 0.001$ & $17.5 \pm 1$ \\
\hline
\end{tabular}

Based on the Arrhenius equation and the experimentally determined model coefficients, activation energies of each reaction were determined. Confidence limits for the activation energies were determined by calculating the activation energies corresponding to the highest and lowest values for the model coefficients. Formation of the product required an activation energy of $17848 \pm 627 \mathrm{~kJ} / \mathrm{kmol}$ and the thermal denaturation needed an activation energy of $111848 \pm 5057 \mathrm{~kJ} / \mathrm{kmol}$. The activation energies for protonation of Asp231 group 
in Amylase and deprotonation of Glu 261 group in Amylase were 67964 \pm 13715 $\mathrm{kJ} / \mathrm{kmol}$ and $160770 \pm 15992 \mathrm{~kJ} / \mathrm{mol}$ respectively. All these activation energies were expressed as $95.3 \%$ confidence intervals.

These activation energy values suggested that the rate limiting step was less affected by temperature compared to the protonation and denaturation of amylase. This agreed with the observation of rapid reduction in enzyme activity at higher temperatures as shown in Figure 2, which suggested that the effect of denaturation has overtaken the effect of increase in kinetic energy when the temperature exceeded $65^{\circ} \mathrm{C}$. According to literature the activation energy for denaturation is $77.6 \mathrm{~kJ} / \mathrm{mol}$ for Bacillus subtilis $\alpha$-amylase, which is a nonthermophilic $\alpha$-amylase type with an optimum temperature of $40^{\circ} \mathrm{C}$, and 316
$\mathrm{kJ} / \mathrm{mol}$ for Pyrococcus furiosus $\alpha$-amylase, which is a hyperthermophilic type of amylase (Brown, Dafforn, Fryer, \& Cox, 2013; Ludikhuyze, Van den Broeck, Weemaes, Hendrickx, \& Tobback, 1997; Raul, Biswas, Mukhopadhyay, Kumar Das, \& Gupta, 2014). The experimentally determined activation energy for denaturation of amylase was close to that of Bacillis subtilis $\alpha$-amylase, which agreed with the rapid reduction in enzyme activity above $65^{\circ} \mathrm{C}$.

In order to further analyse the variation of Model cofficients with temperature and $\mathrm{pH}$, the model coefficients at selected conditions were calculated based on expected values of activation energies. Those results are given in Table 2.

Table 2 Coefficients of the semi-empirical model calculated using activation energies

\begin{tabular}{lllllllll}
\hline $\mathbf{T e m p}$ & $\mathbf{p H}$ & $\mathbf{K}_{\mathbf{d}}$ & $\mathbf{r}_{\mathbf{m a x}}$ & $\mathbf{K}_{\mathbf{4}}$ & $\mathbf{K}_{\mathbf{5}}$ & $\mathbf{K}_{\mathbf{m}}{ }^{\prime}$ & $\mathbf{K}_{\mathbf{m}}$ \\
\hline 50 & 4 & 0.002568 & 0.1013 & $1.07 \mathrm{E}-09$ & 0.00000910 & 6.983 & 83.719 \\
\hline 50 & 5.5 & 0.002568 & 0.1013 & $1.07 \mathrm{E}-09$ & 0.00000910 & 6.983 & 9.412 \\
\hline 50 & 7 & 0.002568 & 0.1013 & $1.07 \mathrm{E}-09$ & 0.00000910 & 6.983 & 7.134 \\
\hline 60 & 4 & 0.005184 & 0.1236 & $6.92 \mathrm{E}-09$ & 0.00002545 & 9.457 & 46.617 \\
\hline 60 & 5.5 & 0.005184 & 0.1236 & $6.92 \mathrm{E}-09$ & 0.00002545 & 9.457 & 10.653 \\
\hline 60 & 7 & 0.005184 & 0.1236 & $6.92 \mathrm{E}-09$ & 0.00002545 & 9.457 & 10.149 \\
\hline 65 & 4 & 0.007252 & 0.136 & $1.685 \mathrm{E}-08$ & 0.00003658 & 10.973 & 40.972 \\
\hline 65 & 5.5 & 0.007252 & 0.136 & $1.685 \mathrm{E}-08$ & 0.00003658 & 10.973 & 11.980 \\
\hline 65 & 7 & 0.007252 & 0.136 & $1.685 \mathrm{E}-08$ & 0.00003658 & 10.973 & 12.852 \\
\hline 70 & 4 & 0.01217 & 0.1469 & 0.00000004 & 0.00005203 & 12.677 & 37.047 \\
\hline 70 & 5.5 & 0.01217 & 0.1469 & 0.00000004 & 0.00005203 & 12.677 & 13.608 \\
\hline 70 & 7 & 0.01217 & 0.1469 & 0.00000004 & 0.00005203 & 12.677 & 17.772 \\
\hline
\end{tabular}

Comparing Table 2 and Table 1, the model coefficients calculated using expected values of activation energies lied within the $95.3 \%$ confidence intervals of experimentally determined coefficients. This suggested that the calculated activation energies could be used to predict mashing behaviour accurately. In previous researches the Michaelis-Menten coefficients for Termamyl $\alpha$ amylase and Liquozyme $\alpha$-amylase, which are used in commercial breweries to catalyze the mashing process, have been analyzed at different conditions. At $65^{\circ}$ $\mathrm{C}$ and $5.5 \mathrm{pH}$, Michaelis Menten coefficient varies within the range of 6.13-10.85 for Termamyl $\alpha$-amylase and 6.03-11.09 for Liquozyme $\alpha$-amylase (Presecki, Blazevic, \& Vasic-Racki, 2013). According to the semi-empirical model, the value of $\mathrm{K}_{\mathrm{m}}$ at similar conditions was 11.980 , which was very close to the literature values. These results suggest that the amylase enzyme naturally present in malt shows similar Michaelis Menten coefficients as commercial enzymes. In order to evaluate the ability of the model to predict mashing behaviour, mashing curves at different conditions were predicted based on expected values of model coefficients and the predicted mashing curves were compared with actual mashing curves. Comparison between predicted and actual mashing curves is shown in Figures 3a-c.

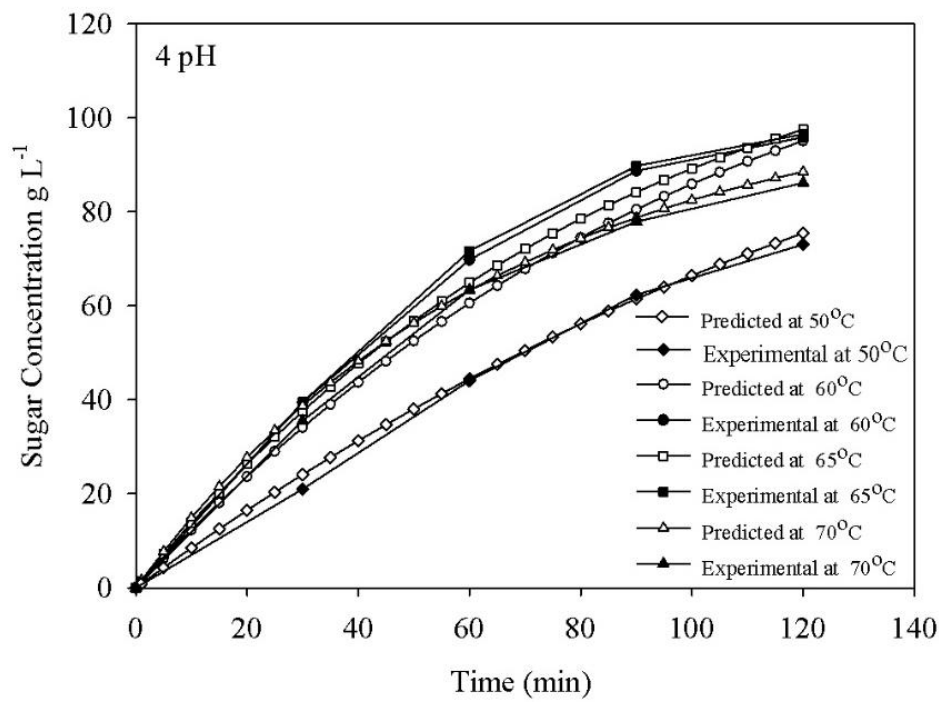

b

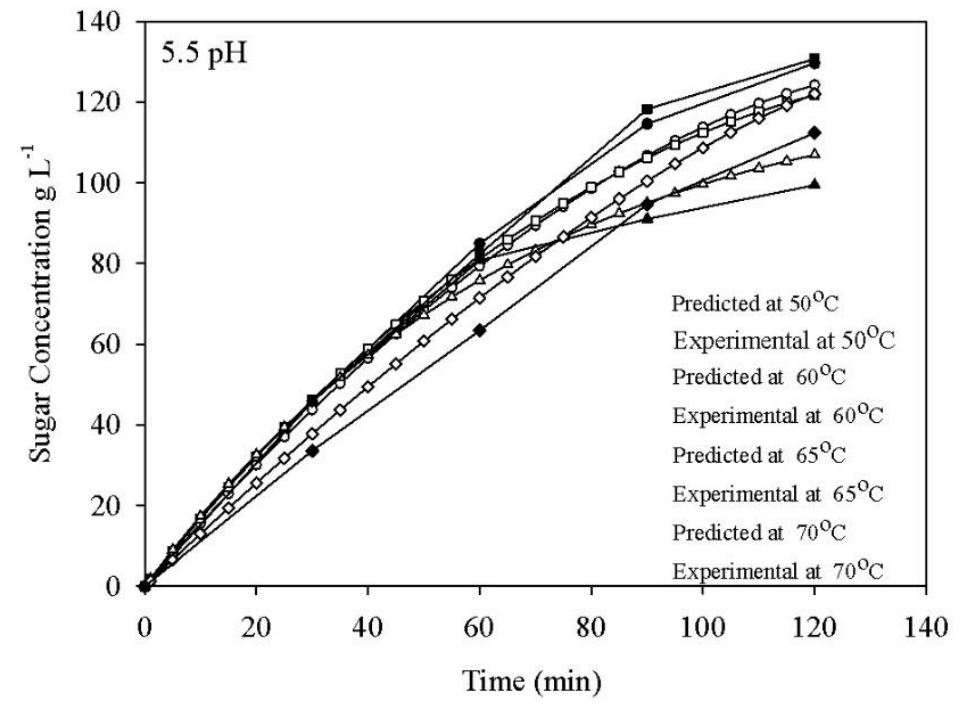




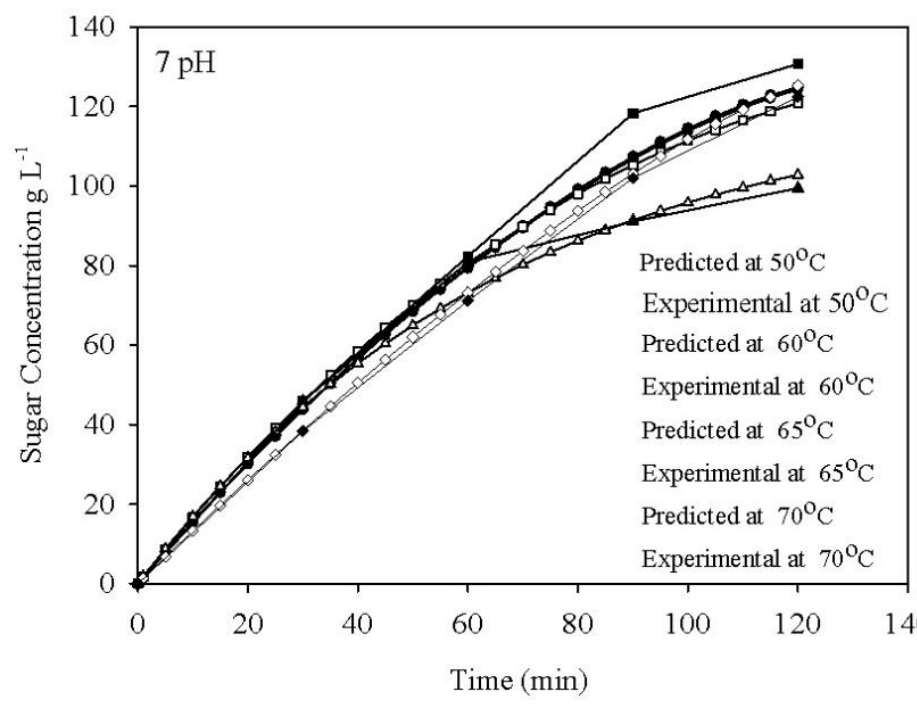

c

Figure 3 Mashing curves experimentally obtained for malt (30\%) and rice (70\%) mixture at temperatures of $50{ }^{\circ} \mathrm{C}, 60{ }^{\circ} \mathrm{C}, 65{ }^{\circ} \mathrm{C}$ and $70{ }^{\circ} \mathrm{C}$, and the curves predicted by the semi empirical model proposed in this study at a) $4 \mathrm{pH}$, b) 5.5 $\mathrm{pH}$ and c) $7 \mathrm{pH}$

The experimental mashing curves showed that the sugar yield increased with the mashing time. When the mashing time reached 2 hours, the rate of sugar production became very low, which could be explained by the denaturation of enzymes. Considering the effect of temperature, the sugar yield at $50^{\circ} \mathrm{C}$ and $70^{\circ}$ $\mathrm{C}$ was considerably low compared to other temperatures at any $\mathrm{pH}$. At $4 \mathrm{pH}$, the lowest sugar yield was observed at $50^{\circ} \mathrm{C}$ and at $5.5 \mathrm{pH}$ and $7 \mathrm{pH}$. Lowest sugar yield is observed at $70^{\circ} \mathrm{C}$. $\mathrm{pH}$ values of 5.5 and 7 had yielded high sugar concentrations compared to $4 \mathrm{pH}$.

As shown in Fig. 4, the model had predicted the mashing behaviour fairly accurately at conditions considered in this work except at $50^{\circ} \mathrm{C} 5.5 \mathrm{pH}, 65^{\circ} \mathrm{C} 7$ $\mathrm{pH}$ and $70^{\circ} \mathrm{C} 7 \mathrm{pH}$ where there was slight deviation from the experimental mashing curves. This deviation may have resulted from either and experimental error or a factor such as product or substrate inhibition, which was not considered in this model.

These mashing curves justify the difference between experimentally determined activation energies for protonation and deprotonation of amylase. The activation energy of deprotonation of amylase is much higher than the activation energy for protonation. Thus, the deprotonation of Glu261, which inhibits the reaction at high $\mathrm{pH}$ values, is more likely to happen at higher temperatures compared to the protonation of Asp231. This behavior could be seen in Fig. 4, where at $70^{\circ} \mathrm{C}$, the sugar yield at $5.5 \mathrm{pH}$ and $7 \mathrm{pH}$ had decreased more drastically compared to that at $4 \mathrm{pH}$.

The accuracy of the models at selected conditions were evaluated based on SSE, $\mathrm{R}^{2}$ and Average absolute percentage error. Those results are shown in Table 3.

Table 3 Correlation between actual results and predicted results

\begin{tabular}{|c|c|c|c|}
\hline & SSE & Avg Error (\%) & $\mathbf{R}^{2}$ \\
\hline $50^{\circ} \mathrm{C} 4.0 \mathrm{pH}$ & 16.225 & 5.08 & 0.9971 \\
\hline $50^{\circ} \mathrm{C} 5.5 \mathrm{pH}$ & 210.267 & 9.98 & 0.9989 \\
\hline $50^{\circ} \mathrm{C} 7.0 \mathrm{pH}$ & 12.954 & 1.64 & 0.9998 \\
\hline $60^{\circ} \mathrm{C} 4.0 \mathrm{pH}$ & 181.517 & 9.20 & 0.9903 \\
\hline $60^{\circ} \mathrm{C} 5.5 \mathrm{pH}$ & 125.804 & 5.52 & 0.9991 \\
\hline $60^{\circ} \mathrm{C} 7.0 \mathrm{pH}$ & 300.261 & 8.78 & 0.9972 \\
\hline $65^{\circ} \mathrm{C} 4.0 \mathrm{pH}$ & 82.183 & 5.42 & 0.9908 \\
\hline $65^{\circ} \mathrm{C} 5.5 \mathrm{pH}$ & 226.717 & 4.84 & 0.9968 \\
\hline $65^{\circ} \mathrm{C} 7.0 \mathrm{pH}$ & 343.989 & 6.94 & 0.9987 \\
\hline $70^{\circ} \mathrm{C} 4.0 \mathrm{pH}$ & 16.540 & 3.24 & 0.9980 \\
\hline $70^{\circ} \mathrm{C} 5.5 \mathrm{pH}$ & 97.496 & 4.55 & 0.9848 \\
\hline $7^{\circ} \mathrm{C} 7.0 \mathrm{pH}$ & 223.569 & 8.93 & 0.9690 \\
\hline
\end{tabular}

According to Table 3 at all conditions, the average error of this model was less than $10 \%$, and the $\mathrm{R}^{2}$ has been greater than 0.95 , which showed that this is a fairly accurate model to predict mashing behaviour.

\section{Prediction of optimum mashing conditions}

This model was used to predict the sugar yield after 2 hours at different temperatures and $\mathrm{pH}$ values. The results predicted by the model are given in Table 4 and graphically interpreted in Figure 4. According to the predicted results, the maximum sugar yield can be obtained at $54-56^{\circ} \mathrm{C}$ and $6.5 \mathrm{pH}$. This is slightly different from the optimum conditions of $50^{\circ} \mathrm{C}$ and $5.5 \mathrm{pH}$ for amylase in barley malt as mentioned in literature (Greenwood \& MacGregor, 1965). However, as shown in Fig. 5, the optimum temperature is heavily dependent on $\mathrm{pH}$ value, and the optimum temperature is high at acidic $\mathrm{pH}$ values. When the $\mathrm{pH}$ value reaches 4 , the optimum temperature reaches $66^{\circ} \mathrm{C}$.

Table 4 Predictions for sugar yield by semi-empirical model

\begin{tabular}{llllllll}
\hline Temp/PH & 4 & 4.5 & 5 & 5.5 & 6 & 6.5 & 7 \\
\hline $\mathbf{5 0}$ & 75.871 & 101.378 & 115.920 & 122.190 & 124.429 & 125.146 & 125.309 \\
\hline $\mathbf{5 2}$ & 81.896 & 105.623 & 118.299 & 123.466 & 125.241 & 125.787 & 125.861 \\
\hline $\mathbf{5 4}$ & 87.204 & 109.055 & 120.034 & 124.291 & 125.707 & 126.116 & 126.101 \\
\hline $\mathbf{5 6}$ & 91.276 & 111.479 & 121.127 & 124.724 & 125.891 & 126.195 & 126.076 \\
\hline $\mathbf{5 8}$ & 93.437 & 112.576 & 121.434 & 124.668 & 125.697 & 125.922 & 125.670 \\
\hline $\mathbf{6 0}$ & 95.198 & 113.257 & 121.388 & 124.309 & 125.216 & 125.352 & 124.908 \\
\hline $\mathbf{6 2}$ & 96.505 & 113.483 & 120.952 & 123.603 & 124.397 & 124.417 & 123.693 \\
\hline $\mathbf{6 4}$ & 97.298 & 113.203 & 120.064 & 122.474 & 123.154 & 123.019 & 121.884 \\
\hline $\mathbf{6 6}$ & 97.624 & 112.469 & 118.764 & 120.947 & 121.497 & 121.148 & 119.428 \\
\hline $\mathbf{6 8}$ & 94.123 & 107.649 & 113.346 & 115.300 & 115.696 & 115.048 & 112.528 \\
\hline $\mathbf{7 0}$ & 88.704 & 100.636 & 105.5491 & 107.177672 & 107.371 & 106.377 & 102.988 \\
\hline
\end{tabular}




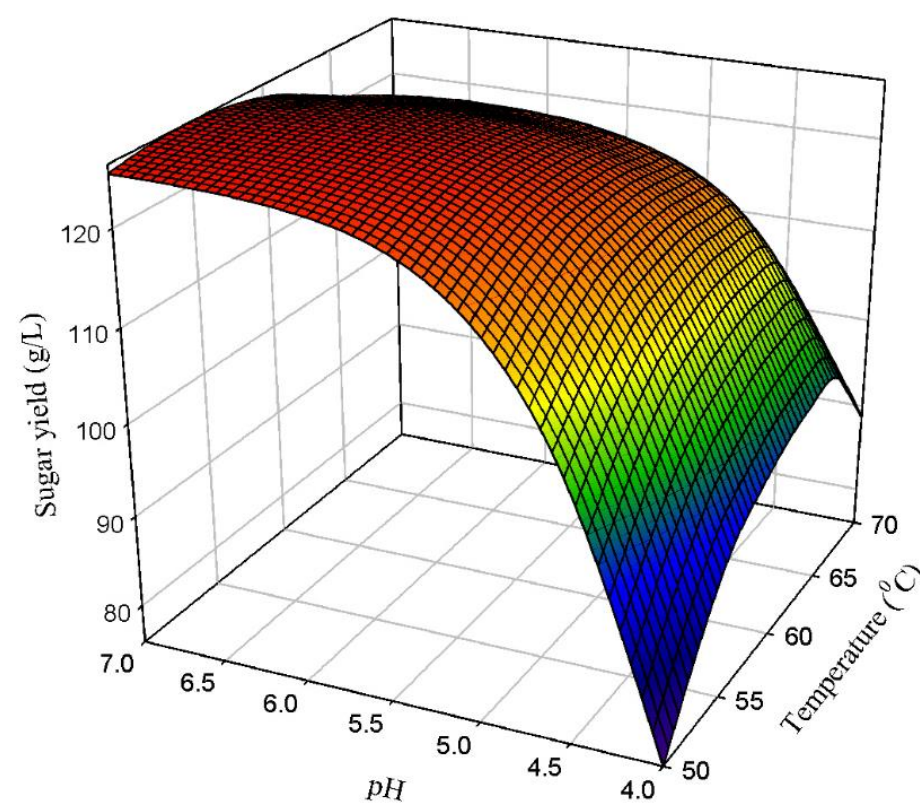

Figure 4 Graphical interpretation of the predictions by the proposed semiempirical model based on theoretical enzyme kinetics and experimental results

These results justify the use of temperature profiles used in the industry. During the mashing process a number of organic acids including mono-, di- and tri hydroxyoctadecenoic acids are formed, causing a reduction in $\mathrm{pH}$ (Kobayashi, Kaneda, Kano, \& Koshino, 1993; Kobayashi et al., 2000). As the optimum temperature is higher at acidic conditions, increasing the operating temperature with time is recommended to get maximum sugar yield. While the exact temperature profile used for brewing depends on a variety of factors including type and source of amylase used and quantity of adjuncts, most industries use temperature profiles in the range of $35-75^{\circ} \mathrm{C}$. According to literature, an optimized mashing profile consisting of $15 \mathrm{~min}$ at $35^{\circ} \mathrm{C}, 15 \mathrm{~min}$ at $45^{\circ} \mathrm{C}, 40 \mathrm{~min}$ at $65^{\circ} \mathrm{C}, 30 \mathrm{~min}$ at $72^{\circ} \mathrm{C}, 10 \mathrm{~min}$ at $78^{\circ} \mathrm{C}$ has yielded more fermentable sugars than constant temperature mashing (Wijngaard \& Arendt, 2006). Therefore, the results of this experiment agree with the use of increasing temperature profiles used in brewing industry.

\section{CONCLUSION}

According to the semi-empirical model of the mashing process, sugar yield can be maximized at $56^{\circ} \mathrm{C}$ and $6.5 \mathrm{pH}$ without external enzyme addition, and the optimum temperature increases as the operating $\mathrm{pH}$ decreases. Since the $\mathrm{pH}$ is not kept constant during industrial mashing process and the wort becomes more acidic during the mashing process due to the formation of organic acids, use of a temperature profile where the temperature is gradually increased within the range of $50-70^{\circ} \mathrm{C}$ in industrial fermentation can be justified. Apprehending the effect of temperature and $\mathrm{pH}$ on the mashing process through these results will be useful for Asian beer manufacturers in order to maximize sugar yield using the adjunct rice which is the main agricultural crop in Asian countries. Besides, since this model is based on a well established theory, this can be easily adjusted to predict the mashing behaviour for different raw materials and different sources of amylase. Possibilities of further research includes incorporating complex factors affecting the mashing process, including aggregation of enzymes, diffusion of substrate and enzyme and substrate and product inhibition.

\section{Nomenclature}

A - Arrhenius constant

$\mathrm{E}$ - Activation energy, $\mathrm{kJ} / \mathrm{kmol}$

(E) - Enzyme concentration, g/l

(E) 0 - Initial enzyme concentration, $\mathrm{g} / \mathrm{l}$

$\mathrm{K}_{1}$ - Rate constant for the bonding of enzyme to the substrate

$\mathrm{K}_{2}$ - Rate constant for the detachment of enzyme from substrate

$\mathrm{K}_{3}$ - Rate constant for conversion of enzyme-substrate complex into product

$\mathrm{K}_{4}$ - Rate constant for bonding of Amylase with $\mathrm{H}+$ ions

$\mathrm{K}_{\mathrm{d}}-$ Thermal Denaturation coefficient, $\mathrm{s}^{-1}$

$\mathrm{K}_{\mathrm{m}}$ - Michaelis-Menten coefficient

$\mathrm{m}_{\mathrm{m}}$ - Mass of malt, $\mathrm{g}$

$\mathrm{m}_{\mathrm{r}}-$ Mass of rice, $\mathrm{g}$

(P) - Product concentration, $\mathrm{g} / \mathrm{l}$

$\mathrm{r}$ - Rate of glucose production, g/l.s $\mathrm{r}_{\max }-$ Maximum possible rate of glucose production, $\mathrm{g} / \mathrm{l} . \mathrm{s}$

$\mathrm{R}$ - Universal gas constant, $\mathrm{J} / \mathrm{mol} . \mathrm{K}$

(S) - Concentration of substrate, $\mathrm{g} / \mathrm{l}$

$\mathrm{T}$ - Temperature, $\mathrm{K}$

$\mathrm{V}$ - Volume of solution, 1

$\mathrm{x}_{\mathrm{m}}-$ Starch fraction in malt by weight

$\mathrm{x}_{\mathrm{r}}-$ Starch fraction in rice by weight

Acknowledgements : The authors would like to express their heartfelt gratitude for the technical staff of the Department of Chemical and Process Engineering, University of Moratuwa for their assistance. The support given by Asia Pacific Brewery by providing malt required for the experiment is also appreciated.

\section{REFERENCES}

Albalasmeh, A. A., Berhe, A. A., \& Ghezzehei, T. A. (2013). A new method for rapid determination of carbohydrate and total carbon concentrations using UV spectrophotometry. Carbohydrate Polymers, 97(2), 253-261. doi:http://dx.doi.org/10.1016/j.carbpol.2013.04.072

Asante, P. K. (2008). Suitability of cassava starch as adjunct substitute for barley in the brewing of beer (MSc.), Kwame Nkrumah University of Science and Technology.

Bajomo, M. F., \& Young, T. W. (1992). DEVELOPMENT OF A MASHING PROFILE FOR THE USE OF MICROBIAL ENZYMES IN BREWING WITH RAW SORGHUM (80\%) AND MALTED BARLEY OR SORGHUM MALT (20\%). Journal of the Institute of Brewing, 98(6), 515-523. https://doi.org/10.1002/j.2050-0416.1992.tb01138.x

Beer production worldwide from 2008 to 2015 , by region Retrieved from http://www.statista.com/statistics/270270/worldwide-beer-production-by-region Biazus, J. P. M., Souza, R. R. d., Márquez, J. E., Franco, T. T., Santana, J. C. C., \& Tambourgi, E. B. (2009). Production and characterization of amylases from Zea mays malt. Brazilian Archives of Biology and Technology, 52, 991-1000.

Briggs, D. (1964). ORIGIN AND DISTRIBUTION OF $\alpha$-AMYLASE IN MALT. Journal of the Institute of Brewing, 70(1), 14-24.

Brown, I., Dafforn, T., Fryer, P., \& Cox, P. (2013). Kinetic study of the thermal denaturation of a hyperthermostable extracellular $\alpha$-amylase from Pyrococcus furiosus. Biochimica et Biophysica Acta (BBA)-Proteins and Proteomics, 1834(12), 2600-2605.

Buckee, G. K., \& Hargitt, R. (1978). MEASUREMENT OF

CARBOHYDRATES IN WORT AND BEER-A REVIEW. Journal of the Institute of Brewing, 84(1), 13-21. https://doi.org/10.1002/j.2050-

0416.1978.tb03832.x

Greenwood, C. T., \& MacGregor, A. W. (1965). THE ISOLATION OF $\alpha$ AMYLASE FROM BARLEY AND MALTED BARLEY, AND A STUDY OF THE PROPERTIES AND ACTION-PATTERNS OF THE ENZYMES. Journal of the Institute of Brewing, 71(5), 405-417. https://doi.org/10.1002/j.20500416.1965.tb06366.x

Greenwood, C. T., \& Thomson, J. (1959). A COMPARISON OF THE STARCHES FROM BARLEY AND MALTED BARLEY. Journal of the Institute of Brewing, 65(4), 346-353. https://doi.org/10.1002/j.20500416.1959.tb01470.x

Kobayashi, N., Kaneda, H., Kano, Y., \& Koshino, S. (1993). The production of linoleic and linolenic acid hydroperoxides during mashing. Journal of Fermentation and Bioengineering, 76(5), 371-375. doi:http://dx.doi.org/10.1016/0922-338X(93)90024-3

Kobayashi, N., Kaneda, H., Kuroda, H., Watari, J., Kurihara, T., \& Shinotsuka, K. (2000). Behavior of Mono-, Di-, and trihydroxyoctadecenoic acids during mashing and methods of controlling their production. Journal of bioscience and bioengineering, 90(1), 69-73. doi:http://dx.doi.org/10.1016/S1389$\underline{1723(00) 80036-5}$

Kongkaew, A., Usansa, U., \& Wanapu, C. (2012). Optimization of wort production from rice malt using enzymes and barley malt. African Journal of Biotechnology, 11(42). https://doi.org/10.5897/AJB11.2303

Lekkas, C., Stewart, G., Hill, A., Taidi, B., \& Hodgson, J. (2005). The Importance of Free Amino Nitrogen in Wort and Beer (Vol. 42).

Lloyd, W. J. W. (1986). ADJUNCTS. Journal of the Institute of Brewing, 92(4), 336-345. https://doi.org/10.1002/j.2050-0416.1986.tb04420.x

Ludikhuyze, L., Van den Broeck, I., Weemaes, C., Hendrickx, M., \& Tobback, P. (1997). Thermal and pressure-temperature denaturation kinetics of bacillus subtilis $\alpha$-amylase: A study based on gel electrophoresis. Food Biotechnology, 11(3), 241-272. https://doi.org/10.1080/08905439709549935

Mallawarachchi, K. S., Bandara, L. R. L. M., Dilshan, S. K. D. H. S., Gunawardena, S. H. P., \& Ariyadasa, T. U. (2016). Optimization of mashing process in beer production using rice as an adjunct. Paper presented at the Moratuwa Engineering Research Conference (MERCON), Moratuwa, Sri Lanka. http://ieeexplore.ieee.org/stamp/stamp.jsp?tp=\&arnumber $=7480155$ \&isnumber $=7$ $\underline{480090}$

Nielsen, J. E., Borchert, T. V., \& Vriend, G. (2001). The determinants of amylase pH-activity profiles. Protein Engineering Design and Selection, 14(7), 505-512. 
Ogbeide, S. O. (2011). Investigating the Use of Sorghum as Malted Barley Adjunct in Brewing Process. Journal of Emerging Trends in Engineering and Applied Sciences, 521-524.

Owuama, C. I. (1997). Sorghum: a cereal with lager beer brewing potential. World Journal of Microbiology and Biotechnology, 13(3), 253-260. https://doi.org/10.1023/A:1018566503879

Pliansrithong, P., Usansa, U., \& Wanapu, C. (2013). Increasing of Nitrogenous Substances in Wort by Using Commercial Enzymes and Modifying Mashing Method. International Journal of Bioscience, Biochemistry and Bioinformatics, 3(4), 404-407. doi:10.7763/IJBBB.2013.V3.243

Poreda, A., Czarnik, A., Zdaniewicz, M., Jakubowski, M., \& Antkiewicz, P. (2014). Corn grist adjunct - application and influence on the brewing process and beer quality. Journal of the Institute of Brewing, 120(1), 77-81. https://doi.org/10.1002/jib.115

Presecki, A. V., Blazevic, Z. F., \& Vasic-Racki, E. (2013). Mathematical modeling of maize starch liquefaction catalyzed by alpha-amylases from Bacillus licheniformis: effect of calcium, $\mathrm{pH}$ and temperature. Bioprocess Biosyst Eng, 36(1), 117-126. https://doi.org/10.1007/s00449-012-0767-4

Raul, D., Biswas, T., Mukhopadhyay, S., Kumar Das, S., \& Gupta, S. (2014)

Production and Partial Purification of Alpha Amylase from Bacillus subtilis (MTCC 121) Using Solid State Fermentation. Biochemistry Research International, 2014, 5. http://dx.doi.org/10.1155/2014/568141

Schuler, M. L., \& Kargi, F. (2002). Bio process Engineering Basic Concepts, 2nd Edition: Prentice Hall.

Sundarram, A., \& Murthy, T. P. K. (2014). Á-Amylase Production and Applications: A Review. Journal of Applied \& Environmental Microbiology, 2(4), 166-175.

Szwed Łukasz, P., Tomaszewska-Ciosk, E., \& Błażewicz, J. (2014). Simplified Mashing Efficiency. Novel Method for Optimization of Food Industry Wort Production with the Use of Adjuncts Polish Journal of Chemical Technology (Vol. 16, pp. 36).

Wijngaard, H. H., \& Arendt, E. K. (2006). Optimisation of a Mashing Program for $100 \%$ Malted Buckwheat. Journal of the Institute of Brewing, 112(1), 57-65. https://doi.org/10.1002/j.2050-0416.2006.tb00708.x

Williams, V. R., Wu, W.-T., Tsai, H. Y., \& Bates, H. G. (1958). Rice Starch, Varietal Differences in Amylose Content of Rice Starch. Journal of Agricultural and Food Chemistry, 6(1), 47-48. http://dx.doi.org/10.1021/jf60083a009 